\title{
Collaboration of Stakeholders In Formation and Development Nagari-Owned Enterprise
}

\author{
Rozidateno Putri Hanida ${ }^{1}$ \\ Bimbi Irawan ${ }^{2}$ \\ Syamsurizaldi ${ }^{3}$ \\ Wewen Kusumi Rahayu ${ }^{4}$
}

\begin{abstract}
Communal land is one of the village assets that can be utilized for the benefit of the public, and it can be managed by an enterprise owned by the village, devoted to creating self-reliance of the village. Law No. 6 of 2014 on the village, mandated the management of the village assets in the form of Village-Owned Enterprise (BUMDes), in West Sumatra, it is called Nagari-Owned Enterprise (BUMNag). Nagari Lubuk Malako has several business fields managed in the form of village cooperative, which later transformed into BUMNag. This paper is the result of a research aimed at describing and analyzing how the collaboration was undertaken by many stakeholders in Nagari, in the formation and development of the BUMNag. With the descriptive qualitative method, through analysis of the data in the form of etic and emic, Nagari Government of Lubuk Malako succeeded in changing the form of the management of the business field of smallholding plantation, to be managed by BUMNag. Changes in the form of management are the result of governance collaboration in Nagari. Stakeholders in Nagari, namely indigenous community, private firms, and youth leaders, worked together to increase participation in doing the vertical and horizontal collaboration, and made networking to push Wali Nagari (Head of Nagari) as the governmental component in order to facilitate the formation and development of BUMNag.
\end{abstract}

\section{Keywords:}

collaboration; stakeholders; Village-owned enterprise (BUMDes);

Nagari-owned enterprise (BUMNag)

\section{Introduction}

Nagari is the lowest administrative nomenclature in West Sumatra Province. It is at the same level as with the village, but it has social and cultural characteristics that are different from Desa in Java and Bali. Nagari, based on the Provincial Regulation West Sumatera No. 9 Year 2000 to 2 Year 2007 concerning the Nagari Government, is the customary law community unit, which consists of a set of a few clans that have territory with its specific demarcated, has a wealth of its own, has the right to organize and manage their own household, and has its own government.

With the enactment of Law No. 6 of 2014 on the village gives a high chance for Nagari to manage the Nagari's wealth. In Chapter $X$, article 85-90 arranged in the formation of Village-owned enterprise or Badan Usaha Milik Desa (BUMDes). BUMDes is a business entity of all or most of the capital is owned by village through direct investments originating from

\footnotetext{
1 Andalas University, Padang, Indonesia. Email: ozidateno@gmail.com

2 BKPM Sumatera Barat Province, Padang, Indonesia. Email: bimbiyes@gmail.com

${ }^{3}$ Andalas University, Padang, Indonesia. Email: s.rizaldi@yahoo.co.id

${ }^{4}$ Andalas University, Padang, Indonesia. Email: wewenkusumi@gmail.com
} 
the wealth of the village separated in order to manage assets, services, and other efforts for the welfare of the villagers. Both article 87 in Law on Village and article 132 in Government Ordinance No. 43 use the phrase "the village can" establish BUMDes.

Lubuk Malako, a Nagari which is located in District of Sangir Jujuan, Solok Selatan Regency, has a number of village assets potentially managed by BUMDes or BUMNag. Based on the type of sector, assets that are owned by Nagari Lubuk, Malako can be grouped into trading sector (the asset is Nagari market), plantation sector (palm oil plantation smallholdings), tourism sector (rivers, small hills, waterfalls, and Pond), mining sector (stone and sand quarries), and water sector.

In an effort to fulfill the mandate of Law No. 6 of 2016, the Nagari Government of Lubuk Malako has potency in managing assets in the form of Nagari-owned enterprise or Badan Usaha Milik Nagari (BUMNag). But in the BUMNag formation, it can not be separated from the role of stakeholders and collaboration among stakeholders. Hesse (2015: 37) defines collaboration as the activity of working together towards a common goal. There are a number of elements included in the definition. The first element is communication, the second element is cooperation, and the third element is responsiveness. As written by Sutoro Eko $(2013 ; 1)$, undeveloped the process of consolidation and cooperation among stakeholders to realize BUMDes as an economic patron that has the role to improve populist economics. It is important to analyze the stakeholders involved in the formation and development BUMNag in Nagari Lubuk Malako, and how collaboration undertaken by existing stakeholders. Through the analysis of stakeholders will be reflected in the interest of every stakeholder, whether the positive or negative impact on the formation of BUMNag, influential stakeholders in decision-making and the role of stakeholders (support and obstacles) in the formation and development of BUMNag. And the analysis of stakeholder collaboration will provide contextual knowledge to us how communication and cooperation must be done by stakeholders to develop BUMNag.

\section{Stakeholders and Their Collaboration in the Formation and Development the Nagari- Owned Enterprise in Nagari Lubuk Malako}

Refers to the Mercier's opinion cited by Salma Damak-Ayadi (2005), stakeholders are "all of the agents for whom the firm's development and good health are of prime concern." And Freeman (1984) defines them as "any group or individual that can affect or be affected by the realization of a company's objectives." Ethical considerations are what have driven stakeholder theory's rise, having been deployed as a way of constructing its normative aspect (the idea being that we are all stakeholders). The stakeholder identification process should regularly be reassessed throughout the project, to ensure that no groups or individuals have been missed (Reed et al., 2009). In this research, the first stage that was done is stakeholders mapping. Mapping is an important step to understanding who your key stakeholders are, where they came from, and what they are looking for in a relationship. Mapping can be broken down into four phases (BSR; 2011, MindTolls; 2015), namely 1) Identifying: listing relevant groups, organizations, and people, 2) Analyzing: understanding stakeholder perspectives and interests, 3) Mapping: visualizing relationships to objectives and other stakeholders, and 4) Prioritizing: ranking stakeholder relevance and identifying issues.

According to the suggestion made by Ronald et al. and quote byFrancisco (2013), stakeholders are players (whether internal or external) that affect or are affected by an organization's objectives or results to a varying extent, which depends on the level to which they have one of three basic attributes: power, 
legitimacy, and urgency. In the case of the formulation of BUMNag in Nagari Lubuk Malako, There are several stakeholders that are involved in the formation of BUMNag di Nagari Lubuk Malako, and they can be grouped into:

1. Internal stakeholders, include Nagari Government of Lubuk Malako, Nagari Consultative Board of Lubuk Malako, Ninik Mamak or group of clan leaders, alim ulama or ecclesiastic, Cadiak Pandai or intellectual group, youth, and entrepreneur.

2. Eksternal stakeholders, come from the local government work units in Solok Selatan Regency include Head of Sangir Jujuan District, Nagari Government Unit in Local Government Secretariat, Community Empowerment Board, Planning Board, Forestry and Plantation Agency, Tourism Agency, Agency of Cooperative, Industry, and Trading, Public Work Agency, investor or company or Sumatera Jaya Agro Lestari Ltd (PT SJAL), and academics.

Collaboration is defined as a cooperative, inter-organizational relationship that was negotiated in an ongoing communicative process and that relies on neither market nor hierarchical mechanisms of control (Lawrence et al., 2000; Heide, 1994; Lawrence et al., 1999; Phillips et al., 2000). Refers to the definition, there are many elements in collaboration, such as cooperation, across organizations, relationships as a basis for negotiating by doing communication between actors.

Simply put, collaboration is a relationship between organizations, between actors who show relationships between actors. To quote what was said by Weber et al. (2007) that the collaboration emphasizes the functions of interorgan namely bureaucratic functions, crossarea policies, and the levels of government that also involve the community. There are three dimensions that were proposed: the vertical dimension, horizontal dimension, and dimension of partnership linkage. The vertical dimension reflects the relationships between government agencies and institutions, citizens and other non-governmental organizations in the lower-level relationships.The horizontal dimension reflects an equal organizational relation. Partnership linkage is described as a mixture of vertical and horizontal relationships resulting in effective arrangement conditions.

Role and Interest of Stakeholders in the Formation and Development the Nagariowned Enterprise in Nagari Lubuk Malako

There are seven internal stakeholders in the formation of BUMNag in Nagari Lubuk Malako. All these stakeholders are involved and have an important role that is very dominant in the formation of BUMNag. Nagari Government of Lubuk Malako, especially Wali Nagari or Head of Nagari Government, has the highest interest in the formation of BUMNag. Nagari's assets such as market, palm oil smallholdings, and tourism objects can be managed by business units of BUMNag. All these objects could potentially generate revenue for the Nagari. With the managed objects in the form of BUMNag, revenue from the management of Nagari communal land become more of legal force. With the revenue for the Nagari government from the BUMNag profit, Nagari also has the interest to improve service to the community and improve the welfare of the community. At the very least, BUMnag provides jobs for Nagari community. Business units of BUMNag, such as oil palm smallholdings offer employment opportunities to Nagari community, especially when they have completed work on their farms. Quite a lot of people who have limited land area, so that when the land is finished, after being used for planting, they no longer have a job on their agricultural land, until plant in the land needs care or harvesting. The idle time can be used by most of the community to work on BUMNag.

To pursue its interests in line with the formation of BUMNag, Nagari Government 
of Lubuk Malako is actively preparing such regulation, Draft Nagari Regulation of formation of BUMNag that would be discussed along with Nagari Consultative Board of Lubuk Malako. Nagari government has also prepared a budget and activities in the fiscal year 2016, as well as prepare existing personnel in the Nagari Government Office of the Lubuk Malako, in order to support the process of formation of BUMNag in Nagari Lubuk Malako.

Institutionally, these are not the obstacles that came from Nagari Government in the formation of BUMNag. Obstacles that were there are more technical in nature, such as limited human resources, and technological limitations. In BUMNag development, the main constraints faced by Nagari government is the ignorance of Nagari government; in determining human resource training for staffs in the business units that exist in BUMNag. Human resources training for staffs in BUMNag business unit is needed in the development BUMNag in the future, but because of the motive of Nagari government that is not based on profit making it is unable to do this. Moreover, there are differences between the BUMNag and Nagari management where BUMNag should be more oriented to profit. For the future, human resources training can be handled directly by BUMNag, and facilitated by the local government work units in Solok Selatan Regency or from other stakeholders, such as PT SJAL.

The second stakeholders considered to have an important role in the formation of BUMNag is Nagari Consultative Board of Lubuk Malako. As an institution that serves as Nagari government partners, or it can be called the legislative institution in village level, the interest of Nagari Consultative Board of Lubuk Malako in the formation of BUMNag is almost the same as the interest of the Nagari Government. Support of the Nagari Consultative Board in discussing Draft Nagari Regulation is a reflection that Nagari Consultative Board realizes that the formation of BUMNag is an urgent need, in order to manage Nagari communal lands which can provide revenue for the Nagari. Nagari Consultative Board also monitors the reports on the business units of BUMNag, especially in the financial statements. Nagari Consultative Board also oversees and approves the use of profits derived from BUMNag to fund programs and activities as outlined in the budget of Nagari Lubuk Malako. Nagari Consultative Board also provides support for the establishment and development of BUMNag business units. For the first stage, Nagari Consultative Board provides support in the management of palm oil smallholdings as a business unit in BUMNag. Nagari Consultative Board is also going to provide support for the formation of the next business units. The next sector that will be decided as a business unit in BUMNag is a Nagari market management. The support provided by Nagari Consultative Board is in accordance with its function as partner, and supervisor on the wheels of government that held by the Government Nagari Lubuk Malako. Institutionally, there are no obstacles that came from the Nagari Consultative Board. The main obstacle is ignorance of member of the Nagari Consultative Board fraction about what BUMNag is. As a new institution where its establishment based on Law No. 6 of 2014 in the village, most of the members of Nagari Consultative Board are not yet known what the BUMNag is actually. They are exactly more familiar with cooperative institution than BUMNag. For Nagari asset management, an institution established to manage Nagari assets more suited in the form of BUMNag compared with a cooperative. Nagari assets such as palm oil smallholdings are not personal property but communal property, so the establishment of BUMNag is more appropriate choice to manage Nagari assets. This ignorance makes some members of Nagari Consultative Board still want oil palm smallholdings, which are administered by a cooperative, not BUMNag. 
Besides the same interest with the Nagari Government and Nagari Consultative Board, Ninik Mamak or group of clan leaders have interests related to communal land ownership. One thing that is very important for Ninik Mamak is the existence of communal land is maintained does not change into belonging to an individual. From a number of stakeholders involved in the formation of BUMNag, Ninik Mamak is the most interested in the status of the communal land.

In addition to communal land ownership status, Ninik Mamak also have an interest in preventing conflicts in the management of communal land. Ninik Mamak as a head of a clan, if there is a conflict, then it is not just a problem for the Nagari government, but actually it is a problem for Ninik Mamak, because the parties in the conflict are members of their own clan with members of other clans. And Ninik Mamak was the most important stakeholders in the conflict resolution than other stakeholders.

Improved service of the Nagari government to the community at its core is a Nagari government interest, but because Nagari community is divided into clans and every clan led by Ninik Mamak, then a good public service to the community indirectly also be an interest for Ninik Mamak. Likewise, Nagari revenue and the availability of employment field, basically also assist the Ninik Mamak as a head of clan in providing jobs and improving the welfare of its members. For poor clan members, they can work on BUMNag business units, and this facilitates Ninik Mamak's duty to provide jobs for its members. BUMNag profit is a source of funds in the program of activities on a budget of Nagari government; some are also aimed at empowering the clans. Thus, the clans have the financial resources to fund the clan's empowerment activities, such as maintenance and construction of the traditional house and the implementation of other cultural activities.

Ninik Mamak consider the formation of BUMNag based on customary perspective, but Cadiak Pandai more looked at from various knowledge perspective, according to the knowledge base and education level they have. In general, Cadiak Pandai interests is almost the same with the interests of Ninik Mamak. Because the people who are in the group of Cadiak Pandai have a higher education level than most other communities; Cadiak Pandai group has an interest in encouraging the development of innovative programs in Nagari that can be financed from communal land management through BUMNag, both programs developed by BUMNag and programs and activities are accommodated in budget of Nagari Lubuk Malako. Obstacles owned by Cadiak Pandai element is the limited authority to implement the idea. In determining the programs and activities, authorities are held by Nagari Government and Nagari Consultative Board. Cadiak Pandai is only one element in Nagari Consultative Board. Related to communal land, the authority is held by Ninik Mamak stakeholders, not Cadiak Pandai.

Alim ulama, although part of one unit of the main stakeholders in Nagari's life, their knowledge in the field of religion make them have a less dominant role in the formation of BUMNag. Although less dominant role, but alim ulama interests are relative importance equal to the interest of Ninik Mamak and Cadiak Pandai. One of its particular interest is to encourage the program in the field of religious and funded by the budget of Nagari Lubuk Malako. BUMNag profit that will be revenue in the budget of Nagari Lubuk Malako is expected to provide funds for Nagari-scale religious activities.

Stakeholders of Ninik Mamak, Cadiak Pandai, and alim ulama are most interested stakeholders to prevent conflict in the formation and development of BUMNag. The position of all the three stakeholders is very important in the life within the villages. They are the local elite, in terms of socio-cultural contexts, education, and religion. Their working relationship is a 
mutual need and cooperates each other, so that they are known as "Tali Tigo Sapilin" or "Tigo Tungku Sajarangan," which means that their roles in life in the Nagari are relatively the same. Likewise, to the conflict, they are most responsible stakeholders in conflict resolution.

The others are the youth and entrepreneur. Youth have an interest in the availability of new jobs, and entrepreneurs can capture the business opportunities that can be done after the BUMNag formed.

For youth, the formation and development of BUMNag create jobs for them. Similarly, the increase in Nagari revenue is one way to be a source of fund for the youth activities, such as art, culture, and sports. Of course, this interest will be fought in the determination of the Nagari budget, and youth is one element in Nagari Consultative Board who will fight for these interests. As one element in Nagari Consultative Board, youth support the discussion of the Nagari regulation draft about the formation and development of BUMNag. Obstacle from youth is a low understanding about BUMNag; the confidence level is still low because BUMNag is too less popular than cooperative, and generally the quality of human resources is low so that the youth can not yet become a trained worker at BUMNag.

For an entrepreneur, the existence of BUMNag provides a source of a new venture for them, it is of particular interests to entrepreneur, in addition to other interests that are relatively similar to other stakeholders. They will get benefit from the multiplier effect of the existence of BUMNag. Especially in the business unit of palm oil smallholdings, they can rent a vehicle to deliver and pick up fresh fruit, bunches of palm oil, and provide for the needs or become a supplier for plantation workers of palm oil smallholdings. Obstacle on entrepreneur is the level of competition is low, so that they will not be able to compete with other competitors. As an institution whose orientation is a profit, BUMNag requires a professional working relationship, and prevent monopoly related to the business that arises with the presence BUMNag.

In addition to the above stakeholders, one of the elements that have interests in the establishment and development of BUMNag, are groups of job seekers. Quite a lot of people have limited agricultural land, so that when they finish processing the land, they will be unemployed. In certain circumstances, they do not have a job, and at that time they can work at the business unit BUMNag palm oil smallholdings. Their hope, BUMNag will recruit them into a freelance employee for a certain period in the business unit of palm oil smallholdings. But when they have to care for and harvest of agricultural land, they can stop working from the business unit of BUMNag. Of a number of elements, this element most expect BUMNag can provide jobs for them with BUMNag existence compared other elements.

Generally, all of the stakeholders have the same interest, namely increased Nagari revenue, improved service to the community, increased community welfare, and no conflict in the management of Nagari communal land. The main obstacle is that some individuals from stakeholders have a poor understanding about BUMNag, and their confidence level about it is still low. Low levels of trust in BUMNag is caused by BUMnag is a new thing, and there has been no case of the best practice of BUMNag in Sumatera Barat Province. Compared with BUMnag, they are more familiar with the cooperative. The distinctive interest and role of the internal stakeholders in the formation of BUMNag in Lubuk Malako can be seen in Table 1.

External stakeholders, which has no direct bearing or not directly involved in the formation of BUMNag, but they have a concern and influential in the formation of BUMNag. Almost all of the external stakeholders came from the local government work units, and they have the same interests related to the 
Table 1.

Interest and the Role of Internal Stakeholder in the Formation of BUMNag

\begin{tabular}{|c|c|c|c|}
\hline \multirow{2}{*}{ Stakeholders } & \multirow{2}{*}{ Distinctive Interest } & \multicolumn{2}{|r|}{ Role } \\
\hline & & Support & Obstacles \\
\hline $\begin{array}{l}\text { Nagari } \\
\text { Government of } \\
\text { Lubuk Malako }\end{array}$ & $\begin{array}{l}\text { The formation of BUMNag legally } \\
\text { under Nagari Regulation, so that } \\
\text { it will be the legal basis in the } \\
\text { management of business units } \\
\text { belonging to Nagari }\end{array}$ & $\begin{array}{l}\text { - Setting up draft of } \\
\text { Nagari regulation on } \\
\text { BUMNag } \\
\text { - Setting up a budget to } \\
\text { discuss draft of Nagari } \\
\text { regulation on BUMNag } \\
\text { - Preparing personnel to } \\
\text { discuss draft of Nagari } \\
\text { regulation on BUMNag } \\
\text { - Propose discussion } \\
\text { of draft of Nagari } \\
\text { regulation to Nagari } \\
\text { Consultative Board }\end{array}$ & $\begin{array}{l}\text { - Limitations of Human } \\
\text { Resources } \\
\text { - Limitations of technology } \\
\text { - Ignorance of Nagari } \\
\text { government in determining } \\
\text { human resource training for } \\
\text { staff in the business units of } \\
\text { BUMNag }\end{array}$ \\
\hline $\begin{array}{l}\text { Nagari } \\
\text { Consultative } \\
\text { Board of Lubuk } \\
\text { Malako }\end{array}$ & $\begin{array}{l}\text { The formation of the BUMNag } \\
\text { legally under Nagari Regulation, } \\
\text { so that it will be the legal basis in } \\
\text { the management of business units } \\
\text { belonging to Nagari }\end{array}$ & $\begin{array}{l}\text { - Discussing draft of } \\
\text { Nagari regulation on } \\
\text { BUMNag } \\
\text { - Supervision of the } \\
\text { business units report on } \\
\text { BUMNag }\end{array}$ & $\begin{array}{l}\text { Understanding of a few } \\
\text { members Nagari Consultative } \\
\text { Board about BUMNag is still } \\
\text { low or poor }\end{array}$ \\
\hline $\begin{array}{l}\text { Ninik Mamak } \\
\text { or group of clan } \\
\text { leaders }\end{array}$ & $\begin{array}{l}\text { - The existence of communal land } \\
\text { as common property or Nagari } \\
\text { property that used for the benefit } \\
\text { of Nagari can be maintained } \\
\text { - BUMNag profit be source of funds } \\
\text { for clan empowerment activities }\end{array}$ & $\begin{array}{l}\text { Support discussion of } \\
\text { draft of Nagari regulation } \\
\text { on BUMNag }\end{array}$ & $\begin{array}{l}\text { - Understanding of a few } \\
\text { members Ninik Mamak } \\
\text { about BUMNag is still low } \\
\text { or poor } \\
\text { - The level of confidence to } \\
\text { BUMNag is still low }\end{array}$ \\
\hline $\begin{array}{l}\text { Alim ulama or } \\
\text { ecclesiastic }\end{array}$ & $\begin{array}{l}\text { BUMNag profit be source of funds } \\
\text { for religious activities in Nagari } \\
\text { level }\end{array}$ & $\begin{array}{l}\text { Support discussion of } \\
\text { draft of Nagari regulation } \\
\text { on BUMNag }\end{array}$ & $\begin{array}{l}\text { - Understanding of a few } \\
\text { members alim ulama about } \\
\text { BUMNag is still low or poor } \\
\text { - The level of confidence to } \\
\text { BUMNag is still low }\end{array}$ \\
\hline $\begin{array}{l}\text { Cadiak Pandai or } \\
\text { intellectual group }\end{array}$ & $\begin{array}{l}\text { - The existence of communal land } \\
\text { as Nagari property that used } \\
\text { for the benefit of Nagari can be } \\
\text { maintained } \\
\text { - The creation of jobs for } \\
\text { community } \\
\text { - Innovative programs in BUMNag } \\
\text { and Budget of Nagari government }\end{array}$ & $\begin{array}{l}\text { Support discussion of } \\
\text { draft of Nagari regulation } \\
\text { on BUMNag }\end{array}$ & $\begin{array}{l}\text { - Understanding of a few } \\
\text { members Cadiak Pandai } \\
\text { about BUMNag is still low } \\
\text { - The level of confidence to } \\
\text { BUMNag is still low } \\
\text { - Limited authority to } \\
\text { implement ideas }\end{array}$ \\
\hline Youth & The creation of jobs for community & $\begin{array}{l}\text { Support discussion of } \\
\text { draft of Nagari regulation } \\
\text { on BUMNag }\end{array}$ & $\begin{array}{l}\text { - Understanding of a few } \\
\text { members Youth about } \\
\text { BUMNag is still low } \\
\text { - The level of confidence to } \\
\text { BUMNag is still low } \\
\text { - Not yet to be trained } \\
\text { workforce }\end{array}$ \\
\hline entrepreneur & $\begin{array}{l}\text { - New business opportunities } \\
\text { associated with the multiplier } \\
\text { effect of formation of BUMNag } \\
\text { - The creation of jobs for } \\
\text { community }\end{array}$ & $\begin{array}{l}\text { Support discussion of } \\
\text { draft of Nagari regulation } \\
\text { on BUMNag }\end{array}$ & $\begin{array}{l}\text { - Understanding of a few } \\
\text { members Youth about } \\
\text { BUMNag is still low } \\
\text { - The level of confidence to } \\
\text { BUMNag is still low } \\
\text { - Less competitiveness }\end{array}$ \\
\hline $\begin{array}{l}\text { Groups of job } \\
\text { seekers }\end{array}$ & Availability of employment & - & $\begin{array}{l}\text { - Quality of human resources } \\
\text { is low, so it can not yet } \\
\text { become a skilled workforce }\end{array}$ \\
\hline
\end{tabular}

Source: The results of the analysis, 2016 
achievement of development indicators in accordance with the duties, functions of each and are not able to perform its role optimally.

Head of Sangir Jujuan District, besides being a local government work units in Solok Selatan, Regency is also a coordinator and a facilitator of development in Nagari, and a liaison between the Regency Government of Solok Selatan and Nagari Government of Lubuk Malako. Interests of Head of Sangir Jujuan Districtin the establishment of BUMNag in Nagari Lubuk Malako is more on success in carrying out the function of a facilitator and coordination in Nagari. It is the success in the achievement of the development indicators of the local government work units. Although Head of Sangir Jujuan District provides support in the establishment and development of BUMNag in Nagari Lubuk Malako,but the obstacle is miss communication between Head of District and Head of Nagari Government often occurred, so it disrupts their working relationship.

Nagari Government Unit, that is one unit in the Local Government Secretariat of the Solok Selatan, which has the function to handle Nagari government affairs. The interests of this element in the formation of BUMNag in Nagari Lubuk Malako, is the establishment of BUMNag in Nagari, which is based on the legal basis in the form of Nagari Regulation. The formation of BUMNag based on NagariRegulation, is a success in the achievement of the performance target at once; it would be the success of development for Nagari Government Unit. The support given by the Nagari Government Unit is merely socializing the formation of BUMNag in Nagari. Barriers that there is a section Nagari administration has not provided the regulation on the establishment of BUMnag in Solok Selatan. The obstacle in Nagari Government Unit is this element, which has not provided the regulation on the establishment of BUMnag in Solok Selatan Regency. Nagari Government Unit also does not have a database of Nagari potential, so that Nagari Government Unit is not able to analyze the potential of the villages that can be managed by BUMNag. Encouragement to set Nagari Regulation of BUMNag would not be meaningful if there is no potential that can be managed by BUMNag. Generally, Nagari Government Unit only play at the level of discourse that is good for the government, and not yet implementable.

Community Empowerment Board of Solok Selatan Regency also has interests related to the success of the development, particularly in community empowerment. Community Empowerment Board of Solok Selatan Regency has not yet provided regulations related to community development through the establishment of BUMNag, and the function as Nagari facilitator and mentoring is not optimal.

Planning Board of Solok Selatan Regency as a leader in the area of planning has not yet planned and budgeted programs, activities related to the establishment and development of BUMNag in Solok Selatan Regency. The absence of the program is budgeted because of the absence of proposals from the local government work units handled BUMNag.

Associated with the business unit that can be developed by BUMNag in Nagari Lubuk Malako, at least four local government work units, which should have a major role in the development of business units of BUMNag. They are Forestry and Plantation Agency, Tourism Agency, Cooperative, Industry, and Trading Agency, and Public Work Agency. Of all of them, only one local government work unit (Forestry and Plantation Agency) which has provided support in the development of BUMNag business unit in the palm oil smallholdings.

In the development of the business unit of BUMNag in Nagari Lubuk Malako, Forestry and Plantation Agency has implemented functions as the facilitator, to agree on the selling price of fresh fruit bunches produced by smallholdings between BUMNag and the buyer 
(PT SJAL). Forestry and Plantation Agency also acts as a mediator if there are problems between a business unit of palm oil smallholdings with PT SJAL associated with the palm oil, especially problem of the palm oil commodity. The obstacles to the Forestry and Plantation Agency is the quality and competence of human resources that can understand the issues of BUMNAg in the plantation sector is still low. In addition, a high mutation in the Government of Solok Selatan Regency also is the cause of the low quality of human resources at the Forestry and Plantation Agency. Human resource has been trained, by mutation, should move to another local government work unit, so that the Forestry and Plantation Agency should train new personnel again.

Sumatera Jaya Agro Lestari Ltd (PT SJAL) is a company that gave palm oil smallholdings to Nagari Lubuk Malako. Palm oil smallholdings is a fee to be paid by PT SJAL when Nagari Lubuk Malako handed over their communal land to PT. SJAL. As many as $10 \%$ of the land that was submitted must be returned to Nagari with the condition that had been planted with the oil palm. The Land that was returned to Nagari was converted be the business unit of BUMNag in Nagari Lubuk Malako. For PT SJAL, if palm oil smallholdings that were submitted to the Nagari managed by BUMNag properly, this condition will make the business activities of PT SJAL be safe without conflict with the community. There will be no interference either from Nagari or individual and group in Nagari to PT SJAL, for both the company and Nagari, as landowner get profit from palm oil plantation. PT SJAL gains a profit from core palm oil plantation, and Nagari gets to profit from palm oil smallholdings. Both infrastructures in core palm oil plantation owned by PT. SJAL and in palm oil smallholdings owned by BUMnag can be used by PT. SJAL and BUMNag. Support provided by the company is to provide easy access for BUMNag, BUMnag business management coaching, and preparation of human resources in BUMNAg business unit. Moreover, PT SJAL is a company engaged in the plantation sector, the plantation business management coaching and giving training to human resources in the business unit of oil palm smallholdings on BUMNag been done by PT SJAL. It is also more effective than the training provided by the local government work unit. There is no obstacle that comes from PT SJAL for BUMNag development. And the company does not want any problem with BUMNag. Instead, if palm oil smallholding management in BUMNag get a problem, it will have an impact on the business activities of PT SJAL. Basically, the condition of a business unit in BUMNag, especially palm oil smallholdings will impact directly proportional to the company or PT ptSJAL.

Other stakeholders who play an important role in the formation and development of the BUMNag are academics of universities in West Sumatra Province. For academics, they have the interests of the development and application of science in the field, how to apply the theory that has been taught in lectures into real-world application. In the drafting of Nagari Regulation on the Formation of BUMNag, academics contribute to do analyzing about the academic study of the Nagari regulation. The obstacle faced academics is limited access, and academics can intervene if there is a request from Nagari government.

Based on the above, the interests and role of external stakeholders can be seen in Table 2 .

\section{Collaboration of Stakeholders in Formation and Development Nagari-Owned Enterprise}

Refers to the policy brief that was written by Barrow (2009), different stakeholders may have different interests in the same resource. While the negotiating and decision-making are important, but it is "who decides" that determines the rights to trees or products thereof. 
Table 2.

Interest and the Role of External Stakeholder in the Formation of BUMNag

\begin{tabular}{|c|c|c|c|}
\hline \multirow{2}{*}{ Stakeholders } & \multirow{2}{*}{ Interest } & \multicolumn{2}{|r|}{ Role } \\
\hline & & Support & Obstacles \\
\hline $\begin{array}{l}\text { Head of Sangir } \\
\text { Jujuan District }\end{array}$ & $\begin{array}{l}\text { - Effective and efficient } \\
\text { implementation of tasks and } \\
\text { functions as a facilitator and } \\
\text { coordinator of development } \\
\text { in Nagari } \\
\text { - The successful of } \\
\text { development that viewed } \\
\text { from the indicators of success } \\
\text { of Local government work } \\
\text { unit } \\
\text { - Improved service to the } \\
\text { community }\end{array}$ & - & $\begin{array}{l}\text { Miscommunication between Wali } \\
\text { Nagari (Head of Nagari Government) } \\
\text { and Head of District }\end{array}$ \\
\hline $\begin{array}{l}\text { Nagari } \\
\text { Government } \\
\text { Unit in Local } \\
\text { Government } \\
\text { Secretariat }\end{array}$ & $\begin{array}{l}\text { - The formation of Nagari- } \\
\text { owned enterprise which is } \\
\text { based on a legal basis in the } \\
\text { form of Nagari Regulation } \\
\text { - Indicators of success of } \\
\text { development }\end{array}$ & $\begin{array}{l}\text { Socialization of } \\
\text { formation of Nagari } \\
\text { Regulation on BUMNag }\end{array}$ & $\begin{array}{l}\text { - The absence of regulation and } \\
\text { counseling on BUMNag in Solok } \\
\text { Selatan Regency } \\
\text { - Do not have data base of Nagari } \\
\text { potency } \\
\text { - Playing at the level of discourse } \\
\text { that is good for the government } \\
\text { but it is not implementable }\end{array}$ \\
\hline $\begin{array}{l}\text { Community } \\
\text { Empowerment } \\
\text { Board }\end{array}$ & $\begin{array}{l}\text { - Indicators of success of } \\
\text { development } \\
\text { - Indicators of success of } \\
\text { development in community } \\
\text { empowerment }\end{array}$ & - & $\begin{array}{l}\text { - The absence of regulation and } \\
\text { counseling on community } \\
\text { empowerment through the } \\
\text { formation of BUMNag } \\
\text { - The function as facilitator and } \\
\text { advisory is not optimal }\end{array}$ \\
\hline Planning Board & $\begin{array}{l}\text { Indicators of success of } \\
\text { development }\end{array}$ & - & $\begin{array}{l}\text { There are no programs and } \\
\text { activities that support the formation } \\
\text { of BUMNag }\end{array}$ \\
\hline $\begin{array}{l}\text { Forestry and } \\
\text { Plantation } \\
\text { Agency }\end{array}$ & $\begin{array}{l}\text { - The success of the } \\
\text { implementation of tasks and } \\
\text { functions in plantation sector } \\
\text { - The success of development }\end{array}$ & $\begin{array}{l}\text { - Facilitate agreement } \\
\text { between BUMNag } \\
\text { and PT SJAL about the } \\
\text { selling price. } \\
\text { - Mediating problem } \\
\text { between BUMNag and } \\
\text { PT SJAL. }\end{array}$ & $\begin{array}{l}\text { - There are no regulations as } \\
\text { guidelines for the formation and } \\
\text { management of the business unit } \\
\text { of palm oil smallholdings. } \\
\text { - The quality and competence of } \\
\text { human resources who understand } \\
\text { the problems in the field of } \\
\text { plantation is still low }\end{array}$ \\
\hline $\begin{array}{l}\text { Tourism } \\
\text { Agency }\end{array}$ & $\begin{array}{l}\text { - The success of the } \\
\text { implementation of tasks and } \\
\text { functions in tourism sector } \\
\text { - The success of development }\end{array}$ & - & $\begin{array}{l}\text { There are no regulations as } \\
\text { guidelines for the formation and } \\
\text { management the business unit of } \\
\text { tourism objects. }\end{array}$ \\
\hline $\begin{array}{l}\text { Cooperative, } \\
\text { Industry, and } \\
\text { Trading Agency }\end{array}$ & $\begin{array}{l}\text { - The success of the } \\
\text { implementation of tasks and } \\
\text { functions in trading sector } \\
\text { - The success of development }\end{array}$ & - & $\begin{array}{l}\text { There are no regulations as } \\
\text { guidelines for the formation and } \\
\text { management of the business unit of } \\
\text { market }\end{array}$ \\
\hline $\begin{array}{l}\text { Public Work } \\
\text { Agency }\end{array}$ & $\begin{array}{l}\text { - The success of the } \\
\text { implementation of tasks and } \\
\text { functions in sanitation sector } \\
\text { - The success of development }\end{array}$ & - & $\begin{array}{l}\text { There are no regulations guidelines } \\
\text { for the formation and management } \\
\text { of the business unit of drinking } \\
\text { wáter }\end{array}$ \\
\hline $\begin{array}{l}\text { Company (PT } \\
\text { SJAL) }\end{array}$ & $\begin{array}{l}\text { - When business unit of } \\
\text { BUMNag especially pal oil } \\
\text { smallholdings managed well, } \\
\text { the activity of PT SJAL will be } \\
\text { safely }\end{array}$ & $\begin{array}{l}\text { - } \text { BUMNag can } \\
\text { use utility and } \\
\text { infrastructure in core } \\
\text { palm oil plantation } \\
\text { belonged to PT SJAL }\end{array}$ & - \\
\hline
\end{tabular}


connection from page 222

\begin{tabular}{|c|c|c|c|}
\hline & $\begin{array}{l}\text { - PT SJAL can use access or } \\
\text { infrastructure in palm oil } \\
\text { smallholdings }\end{array}$ & $\begin{array}{ll}\text { - } & \text { BUMNag business } \\
\text { management } \\
\text { coaching } \\
\text { - Training for BUMNag } \\
\text { staffs }\end{array}$ & \\
\hline Academics & Development of science & $\begin{array}{l}\text { Analysing about } \\
\text { academic study of the } \\
\text { Nagari regulation }\end{array}$ & Limited Access and authority \\
\hline
\end{tabular}

Source: The results of the analysis, 2016

Figure 1.

Mapping the stakeholders based on the power and interest in the formation of BUMN in Nagari Lubuk Malako

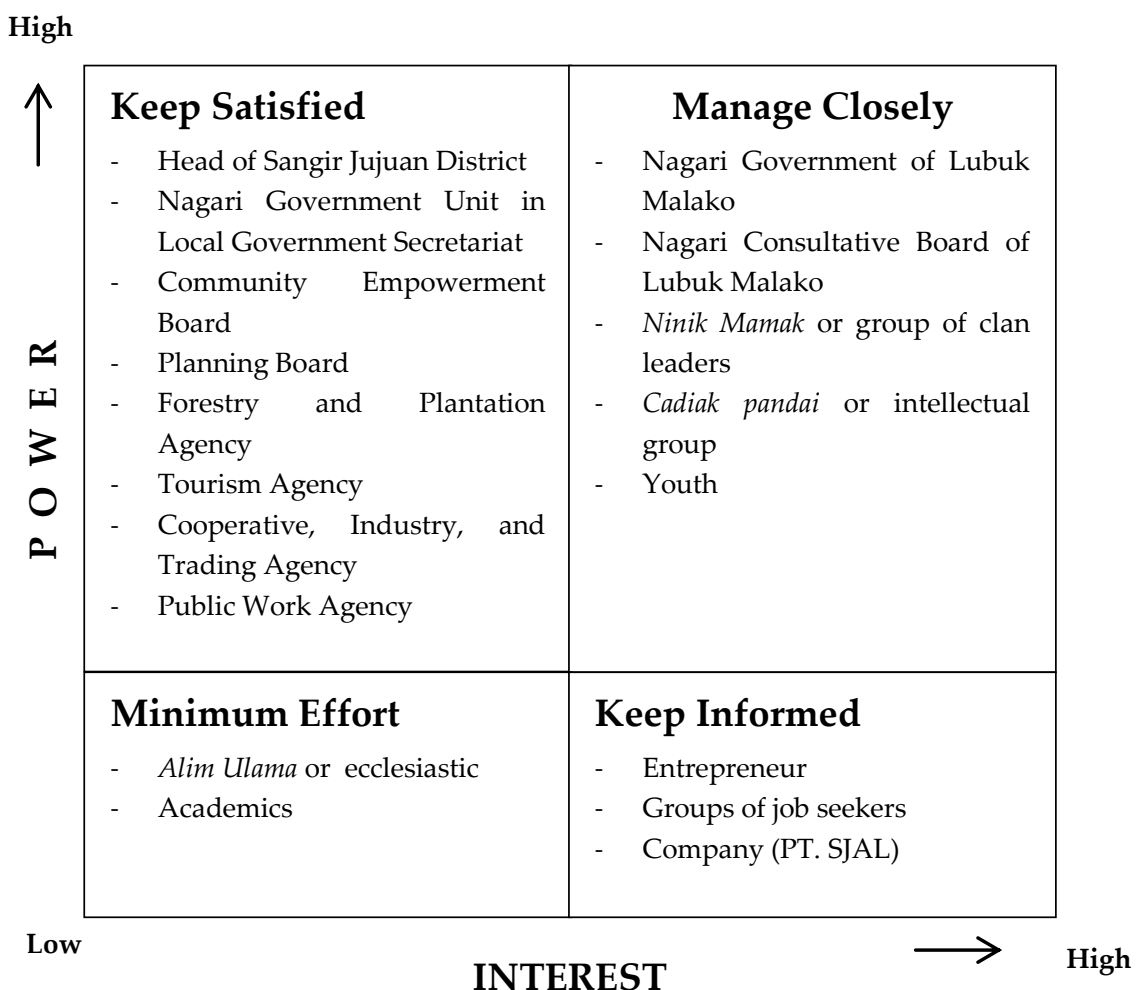

Source: The results of the analysis, 2016

In the formation of BUMNag in Nagari Lubuk Malako, based on its power and interest, stakeholders can be grouped into manage closely, keep satisfied, and minimum effort as shown in Figure 1.

Stakeholders that classified as manage closely are the stakeholders who have a high level of interest in the formation of BUMNag and have high power in decision-making in the formation of BUMNag. Each stakeholder will secure their own interests. In this case, there are no conflicting interests among stakeholders, so that it will not obstruct the process of the formation of the BUMNag. The existence of communal land will be maintained is the most important interest, and all stakeholders will want to pay attention to this interest. Although this is Ninik Mamak's interest, but it will be paid by Cadiak Pandai or intellectual group, youth, Nagari government, and also 
Nagari consultative Board. When this interest can be accommodated, there is no obstacle in the formation of BUMNag, as well as facilitate the way in achieving the goals to establish the BUMNag.

Stakeholders in the minimum category effort are the entrepreneur and alim ulama or ecclesiastic. Ecclesiastic, even when it is part of the essential elements in Nagari's life, but the ecclesiastic do not have a high interest in the formation of BUMNag. Likewise, the influence of the ecclesiastic is also low in terms of the formation of BUMNag. The entrepreneur also does not have a high level of interest in the formation of BUMNag, because the businesses are done to the communal land, so that it does not interfere with the entrepreneur business. Employers will only take an interest in obtaining multiplier effect on the formation of BUMNag.

Stakeholders are included in the category keep satisfied, do not have a high interest in the formation of BUMNag, but they have a relatively high power, especially in supporting the discussion of draft Nagari regulation, and the provision of related regulations in the formation of BUMNag. In the case of the formation of BUMNag in Nagari Lubuk Malako, almost all stakeholders in this category is not able to bring up the roles associated with power held in support of the formation BUMNag.

Each stakeholder carries out his interests and keeps his power in balance. In order to make the balance to be well built, it requires collaboration among stakeholders. The collaboration will have an impact on stakeholders with high power, but low interests in the establishment and development of BUMNag. Through collaboration, Stakeholders with high power but low interests will absorb information from stakeholders with low power but high interests, so with the power, it will facilitate the establishment and development of BUMNag. Stakeholders with high power but low interests can give more attention to the development of BUMNag. Stakeholders with low power and low interests become more empowered, because of the collaboration with stakeholders with high power but low interests. Stakeholders with high power and high interests, they will facilitate the establishment and development of BUMNag with regulation and the regulation will avoid conflict.

There are three forms of dimension in stakeholder collaboration in the formation and development of BUMnag in Nagari Lubuk Malako namely horizontal, vertical, and partnership linkage. The dimension form in the collaboration can be seen in Figure 2.

Based on Figure 2, the horizontal dimension occurs in three stakeholder groups. The first group is collaboration among stakeholders which are local government work units at regency government level; the second group is stakeholders at the Nagari government level, and the third group of other stakeholders, which are not an institution of the agency, district, or Nagari government level. Stakeholder at district level does not engage in horizontal dimension, because there is only one stakeholder at district government level that is involved in the formation and development of BUMNag in Nagari Lubuk Malako.

The form of horizontal dimension in stakeholder collaboration, which are local government work units at the regency government level is communication in reaching their respective interests. Meanwhile, their level of importance in the formation and development of BUMNag is low, they are relatively more concerned with communication to the extent of their achievement in achieving the performance targets, as a local government work unit at the regency level compared with the Nagari government's goal of establishing and developing BUMNag that will increase Nagari revenues. Conversely, communication in horizontal dimension in collaboration between stakeholders at the Nagari government level is more concerned with achieving the formation and development 
Figure 2.

Dimension Forms in Collaboration among Stakeholders in the Formation and Development of BUMNag in Nagari Lubuk Malako

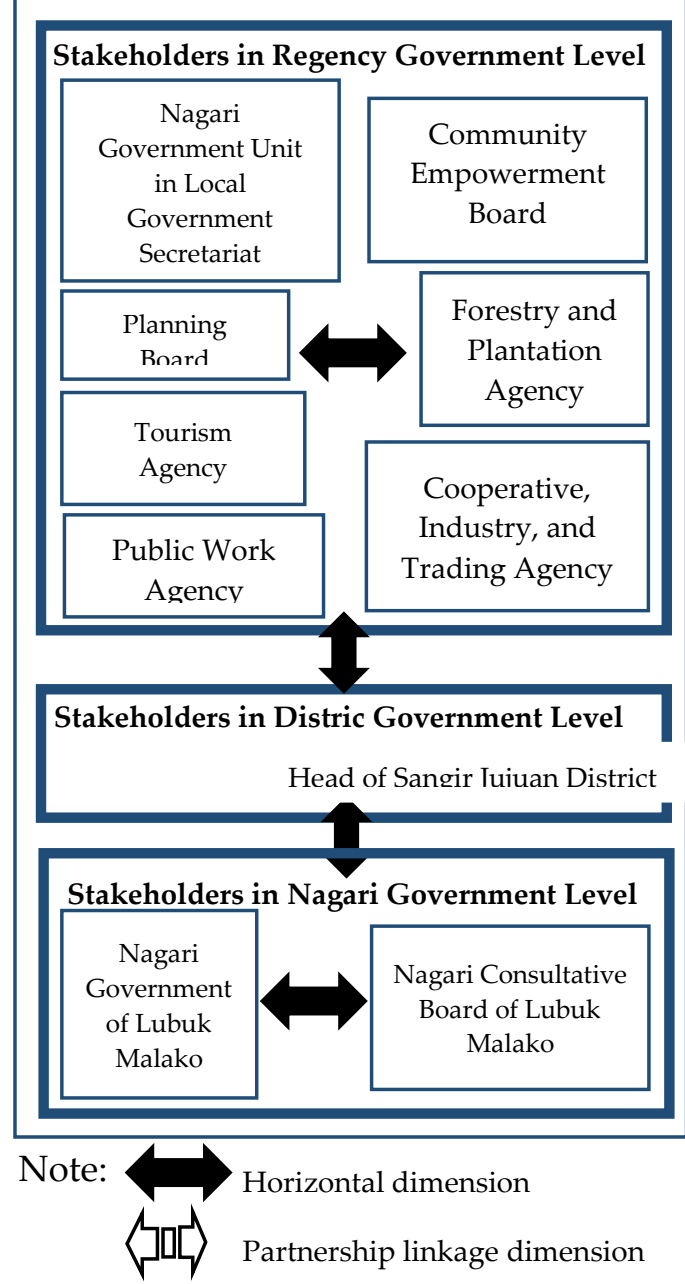

Source: The results of the analysis, 2016 of BUMNag in Nagari Lubuk Malako. They are stakeholders whose level of interest is high with a high level of power as well.

Vertical dimension in collaboration is carried out by being among stakeholders at different government level, i.e., collaboration conducted by stakeholders at the regency government level with district government level, regency with Nagari, and districts with Nagari. In the vertical dimension, the elements created not only communication but also cooperation. For Nagari Government of Lubuk Malako and Nagari Consultative Board of Lubuk Malako, the role of stakeholders that

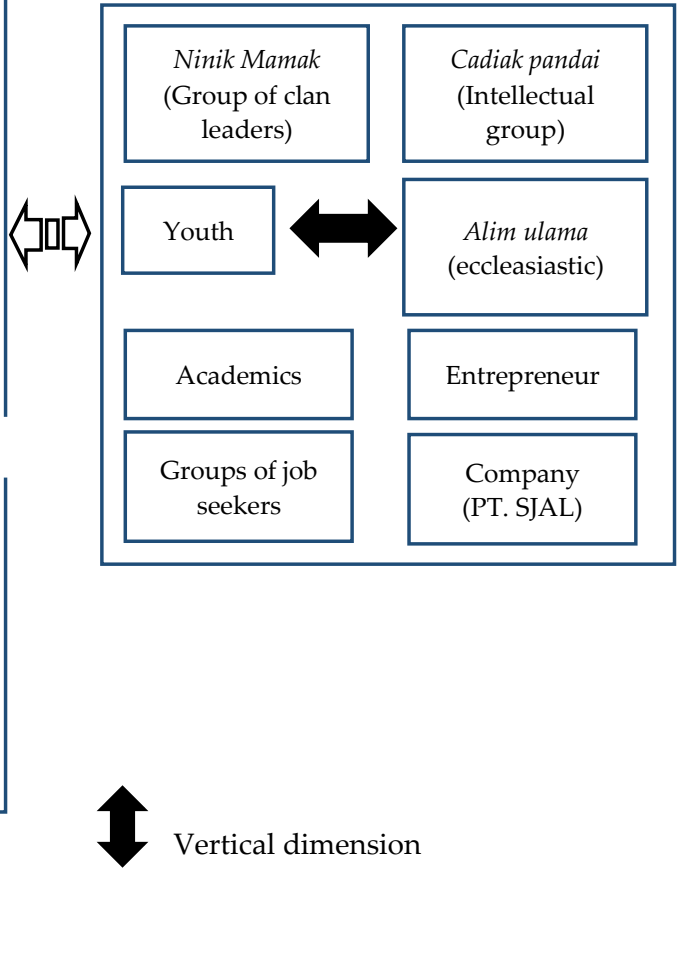

also have functioned as local government work units at regency and district levels is needed because they have high power that can accelerate the formation and development of BUMnag in the Nagari. The formation of BUMnag becomes the performance target for local government work units at the regency level, stakeholders at the Nagari government level establish cooperation with stakeholders at the regency level, so that they are able to assist the establishment and development of BUMnag in Nagari Lubuk Malako optimally

Partnership linkage dimension in collaboration implemented by stakeholders 
at government level with other stakeholders. In the vertical and horizontal dimensions, stakeholders are bound by their respective authorities who are entirely accountable to the Bupati as the regency head. The relationship between stakeholders that have functioned as local government work unit at the regency level, and other stakeholders have no ties in terms of authority. And the other stakeholders are able to penetrate the authority of stakeholders at all levels of government. Therefore, the partnership linkage dimension in this collaboration involves an element of responsiveness in addition to communication and cooperatives. Responsiveness is needed, so that all stakeholders can cooperate in the formation and development BUMNag, as well as to realize their respective interests.

\section{Conclusion}

In the case of the formation of BUMNag in Nagari Lubuk Malako, stakeholders were included in the category of key players, which is a major determinant of success or failure of the formation of BUMNag. All stakeholders in this category are able to perform the role according to the height of power or interest they have, so that their interests can be accommodated without eliminating other interests. They can work together in a mutual cooperation, so that all the interests can be accommodated. While stakeholders are included in the category contest setter do not carry out the role, even when their powers or influences are very high. Their role would likely be a catalyst in the formation of BUMNag in Nagari Lubuk Malako, especially they do not have a direct interest in the formation of BUMNag. In the formation and development of BUMNag, The Government of Nagari Lubuk Malako has conducted a collaboration involving three dimensions of horizontal, vertical, and partnership linkage, as well as doing 3 elements contained in the dimensions i.e communication, cooperation and responsiveness. These three dimensions make the Nagari Government of Lubuk Malako successful in the formation and development BUMnag in Nagari Lubuk Malako.

\section{References}

Barrow, E., Clarke, J., Grundy, I., Jones, K-R., \& Tessema, Y. (2002). Analysis of stakeholder power and responsibilities in community involvement in forest management in Eastern and Southern Africa.Kenya: Laba Graphics Services.

Sutoro, E. (2013). [Membangun BUMDes Mandiri Kokoh dan Berkelanjutan]. Policy Paper.

Hesse, F., Care, E., Buder, J., Sassenberg, K., \& Griffin, P. (2015). A framework for teachable collaborative problem solving Skills. In Patrick G. \&Esther C. (Eds.), Assessment and Teaching of $21^{\text {st }}$ Century Skills: methods and approach. Dordrecht: Springer.

Agüera, F. O. (2013). Stakeholder theory as a model for sustainable development in ecotourism. TURYDES, 6(15).

Heide, J. B. (1994). Interorganizational governance in marketing channels. Journal of Marketing, 58(1),71-85. doi: 10.2307/1252252

Lawrence, T. B., Phillips, N., \& Hardy,C. (1999). Watching whale-watching: exploring the discursive foundations of collaborative relationships. The Journal of Applied Behavioral Science, 35, 479-502. doi: 10.1177/0021886399354008

Lawrence,T.B., Hardy, C., \& Phillips, N. (2002). Institutional effects of interorganizational collaboration: the emergence of protoinstitutions. Academy of Management Journal, 45(1), 281-290. doi: 10.2307/3069297

Mind Tools. (2015). Stakeholder Management: Winning Support for Your Projects. Retrieved from https://www.mindtools. com/blog/corporate/wp-content/uploads/ sites/2/2015/07/Stakeholder-Management10-Minute-Guide.pdf 
Phillips, N., Lawrence, T. B., \& Hardy, C. (2002). Inter-organizational collaboration and the dynamics of institutional fields. Journal of Management Studies, 37(1).

Reed, M. S., Graves, A., Dandy, N., Posthumus, H., Hubacek, K., Morris, J., . . . Stringer, L.C. (2009). Who's in and why? A typology of stakeholder analysis methods for natural resource management. Journal of Environmental Management, 90(5), 19331949.
Rozaki,A., etc. (2015). Membangun Kemandirian Desa Melalui BUMDes. Yogyakarta. Institute for Research and Empowerment (IRE).

Pesqueux, Y., \& Damak-Ayadi, S. (2005). Stakeholder theory in perspective. Corporate Governance: The International Journal of Business In Society, 5(2), 5-21.

Weber, E. P,Lovrich, N. P., \& Gaffney, M. J. (2007). Assessing collaborative capacity in a multidimensional world. Administration E Society, 39(2), 94-220. 